\title{
Intersectorality in the governance of inland fisheries
}

\author{
$\underline{\text { Andrew M. Song }}^{1,2}, \underline{\text { Shannon D. Bower }}^{3}, \underline{\text { Paul Onvango }}^{4}$, Steven J. Cooke $^{3}, \underline{\text { Shehu L. Akintola }}^{5}, \underline{\text { Jan Baer }}^{6}, \underline{\text { Tek B. Gurung }}^{7}, \underline{\text { Missaka }}$

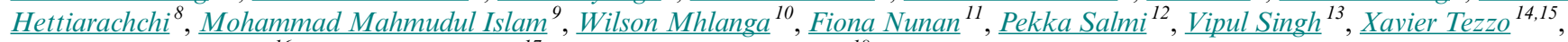 \\ $\underline{\text { Simon J. Funge-Smith }}{ }^{16}$, Prateep K. Navak ${ }^{17}$ and Ratana Chuenpagdee ${ }^{18}$
}

\begin{abstract}
One of the defining characteristics of inland fisheries is that they are closely impacted by other essential human activities that rely on the same fresh or brackish water ecosystems, such as hydroelectricity generation and irrigated agriculture. Starting with the premise that an understanding of fisheries' interactions with these external sectors is in itself critical for achieving sustainability of the fisheries, this paper explores the topic of intersectoral governance and outlines an approach to analyzing the intricate and often challenging sector relationships. By drawing on examples of inland fisheries from around the world, the paper proposes four broad discursive mechanisms that can structure the study of the intersectoral dynamics, i.e., system characterization, valuation, power relations, and vertical policy interaction. A synthesis model then demonstrates their interwoven nature, revealing the way each mechanism influences one another as together they shape overall outcomes. It is apparent that analyses often need to be combined to advance more rigorous (and transdisciplinary) science and also inform appropriate courses for the governance of inland fisheries. Given the typically marginal position of fisheries in inland water-use discussions, we call for a more systematic understanding of intersectoral interactions to enhance the sector's resilience within the wider society and subsequently contribute to integrated governance of waterbodies.
\end{abstract}

Key Words: cross-sectoral relationships; inland fisheries; integrative environmental governance; valuation; water-energy-food nexus

\section{INTRODUCTION: BENEFITS AND PLIGHTS OF INLAND FISHERIES}

Inland fisheries (fresh and brackish water) distributed across the globe generate many ecosystem services, including provision of benefits to human wellbeing (Dugan et al. 2010, Lynch et al. $2016 b$ ). Inland fish tend to be widespread and accessible due to the numerous and dispersed locations of fish-bearing inland waterbodies in diverse natural and manmade landscapes (Welcomme et al. 2010). The public ownership and typically openaccess nature of many such waterbodies, low entry costs, and relatively simple gear technology required to engage in inland fisheries have allowed them to be a historical source of livelihood and food production. Inland fish can offer an affordable form of animal protein and essential micronutrients, such as omega-3 fatty acids, calcium, vitamin A, iron, and zinc (Craviari et al. 2008, Youn et al. 2014). This food and nutritional function of inland fish is particularly crucial to those who have limited options, e.g., the rural poor in developing and net food-importing countries and other vulnerable groups such as young children, pregnant women, and the sick and elderly who often rely on fish for subsistence and cash income. The inland fishery sector through its harvest and postharvest activities also employs about 61 million people around the globe, of which $50 \%$ are women (Bartley et al. 2015), making it an economically significant industry. At a regional scale, the annual total inland fish production in the Lower Mekong Basin in 2008 was estimated at about 3.9 million tonnes and valued at U.S.\$7 billion (Mekong
River Commission (MRC) 2010). Similarly, the annual net value of the recreational fishing sector in the Laurentian Great Lakes and European freshwater bodies is estimated to be U.S. $\$ 1.5$ billion and U.S.33 billion, respectively, while also generating about $\$ 70$ billion to the global GDP annually (Food and Agriculture Organization (FAO) 2010, World Bank 2012, Poe et al. 2013).

In recent decades, the sustainability of inland fisheries is said to be under severe threat (Welcomme et al. 2010, Cooke et al. 2016). Overexploitation, the decline of fish biomass, particularly on sensitive stocks, and the decreasing viability of commercial and recreational fishing enterprises are all common concerns (Cooke and Cowx 2004, Allan et al. 2005, Cowx et al. 2010). It is presumed that most inland fisheries are fished close to their biological limits. Although tropical inland fisheries and floodplain fisheries are known to be surprisingly resilient, sustained or increased fishing pressure would eventually impact biodiversity with the loss of larger long-lived species (Dugan et al. 2010). The dispersed and small-scale nature of inland fisheries, combined with the shortage of financial and technical resources faced by many governments, especially in the developing world, to monitor the harvest and stock trends, makes it challenging to obtain accurate information on the status of fisheries, further complicating management effectiveness (Bartley et al. 2015, Lorenzen et al. 2016).

The need for greater attention on intersectoral linkages Arguably, the greatest risks to the sustainability and resilience of inland fisheries originate from outside the fishery sector (and

\footnotetext{
${ }^{1}$ ARC Centre of Excellence for Coral Reef Studies, James Cook University, Australia, ${ }^{2}$ WorldFish, Solomon Islands, ${ }^{3}$ Carleton University, Canada, ${ }^{4}$ University of Dar es Salaam, Tanzania, ${ }^{5}$ Lagos State University, Nigeria, ${ }^{6}$ Fisheries Research Station of Baden-Württemberg, Germany, ${ }^{7}$ Nepal Agricultural Research Council, Kathmandu, Nepal, ${ }^{8}$ School of Earth and Environmental Sciences, University of Queensland, Australia, ${ }^{9}$ Department of Coastal and Marine Fisheries, Sylhet Agricultural University, Bangladesh, ${ }^{10}$ Bindura University of Science Education, Zimbabwe, ${ }^{11}$ International Development Department, University of Birmingham, UK, ${ }^{12}$ Natural Resources Institute Finland (Luke), Finland, ${ }^{13}$ University of Delhi, India, ${ }^{14}$ WorldFish, Myanmar, ${ }^{15}$ Wageningen University, The Netherlands, ${ }^{16}$ Food and Agriculture Organization of the United Nations, Rome, Italy, ${ }^{17} \mathrm{School}$ of Environment, Enterprise and Development, Environmental Change and Governance Group, Faculty of Environment, University of Waterloo, Canada, ${ }^{18}$ Memorial University of Newfoundland, Canada
}

Erratum: The Established Reference format was incorrect in the original publication. It was changed on 4 May 2018. 
beyond fishing activities) (FAO 1997, Cowx 2002, Cowx et al. 2010, Beard et al.2011). Important societal needs such as drinking water, irrigation for agriculture, power generation, navigation, and effluent disposal all rely on the waterbodies in which inland fisheries are also based. Associated impacts from these activities, including habitat degradation, water pollution, and flow modification, are considered the major constraints to the sustainable development of lake and river fisheries, and to a greater degree, to the protection of aquatic biodiversity (Cowx 2002). Indepth accounts of these nonfishing-induced effects have been documented elsewhere, thus are not detailed in this article (e.g., see Dugan et al. 2010; also, dam construction: Orr et al. 2012, Winemiller et al. 2016; water pollution: Adeyemo 2003, Vörösmarty et al. 2010; irrigation: Craig et al. 2004, NguyenKhoa and Smith 2004; climate change: Ficke et al. 2007, Lynch et al. 2016c). In sum, surrounded by these external pressures, managing inland fisheries has been a challenging and frustrating, and sometimes even a futile, endeavor. Coupled with the relatively little attention paid to the long-term integrity of inland waterbodies, inland fish are considered one of the most endangered groups of species in the world (Jenkins 2003, Dudgeon et al. 2006), and freshwater habitats (including brackish environments) among the most altered and threatened ecosystems (Brönmark and Hansson 2002, Malmqvist and Rundle 2002), with many experiencing a critical transition or a regime shift (Nayak et al. 2016).

In light of the multiuse patterns of inland waters, these fisheries have usually been given lower priority and relegated to a peripheral position (Arlinghaus et al. 2002, Cowx 2002), whose ensuing marginalization has succinctly been summarized as a case of "forgotten fisheries" (Cooke et al. 2016). This marginal recognition has meant that there is often a lack of coordination and little structured communication between fisheries management authorities and other sectoral institutions, effectively insulating fisheries concerns in the resource allocation and decision-making processes (Arlinghaus et al. 2002, Cowx et al. 2010). Low political power is also reflected in the absence of separate legislative treatment of inland fisheries in many countries (Welcomme 2001). It follows that the priorities and perspectives of fishing industry and communities are often sidelined as those of other sectoral developments are favored. So why are fisheries receiving insufficient attention in this debate? The prevailing explanation indicates an economic rationale, as stated by Cowx et al. (2010: 2203), "water resource development schemes are a particular problem because the economic value of such schemes outweighs the presumed fisheries, biodiversity and conservation values of the aquatic ecosystem..." In this logic, decision makers (including government regulators) would align with the sector that promises the highest perceived economic value to society, hence supporting options that often generate the biggest shortterm payoffs (Brummett et al. 2013). This uneven status is exacerbated by the perceived differences in the scale to which sectoral benefits accrue. Watershed developments are typically reported to provide benefits relevant at the national level (e.g., electrical grid expansion or large-scale food production from irrigated agriculture) whereas most inland fisheries products are predominately traded regionally, locally, or used for household consumption in the absence of formal structured markets. Cooke et al. (2014: 1598) admit that "the locality-based focus of fisheries creates inherent limits because it is difficult to get the wider society to care about places that are not part of their daily lives."

Ultimately, whether the interests of inland fisheries are recognized in watershed utilization dialog depends on their societal status, that is, how they are seen in the public eye (Arlinghaus et al. 2002). Notable challenges exist in elevating public admiration. Fishers have been often categorized as the "poorest of the poor" by the political elite (Béné 2003). In many places, the public also seems unaware of the links between fish production, food security, aquatic biodiversity, and habitat change for proximate waterbodies, let alone for distant locations (Cooke et al. 2014). Vaidyanathan (2011: 306) in referring to the Mekong River has noted that "it is hard for people in Europe or North America to imagine the role that freshwater capture plays in terms of food security, economically and even culturally..." In developing countries, too, maintaining strong connections to fish and fisheries is a challenge, as the rate of urbanization and modernization accelerates (Cooke et al. 2013). Lastly, the societal response to climate change with predicted increased incidence of drought and flooding has almost always been to build more dams and increase control of water for agriculture and domestic use. In the face of more extreme weather events, with damming and irrigation taking greater precedence, the visibility of fisheries would further fade away in the public mind (Brummett et al. 2013).

The lack of coordination between fisheries and other sectors reflects wider concerns within literature and practice on environmental governance. Although the governance of many natural resources is led by a specific sector, such as energy, tourism, or agriculture, interactions across sectors are recognized as frequent, resulting from the multiple uses of the resources and occurring at several administrative levels (Lubell 2013, VisserenHamakers 2015). Many studies have over time examined resource interactions and environmental externalities. However, not much is written specifically about the governance aspect of the "intersectorality." Visseren-Hamakers (2015: 141) observes that "little attention has been paid to the relationships between governance systems" and advocates for a shift to "integrative environmental governance" where focus is not on the design, development, and implementation of an individual new policy per se, but more on the relationships between different sectors as a whole, taking into account power imbalances, political struggles, and win-lose situations that are commonly observed. Recent writing on this issue from a theoretical angle has begun to elaborate on the coordination difficulties that policy makers might face (or end up ignoring) in attaining a coherent waterenergy-food nexus (see Weitz et al. 2017). In complementing this conceptual expansion, this paper from the perspective of inland fisheries contributes to an applied understanding of the challenges of, and potential for, achieving a more comprehensive and fair representation of the diverse sectors involved in the governance processes with an ultimate aim of striving for more balanced sectoral coordination.

\section{An inductive understanding of intersectoral interactions}

Despite availability of much case study information, research on inland fisheries has been mainly "parochial, with a strong national orientation and few theoretical frameworks guiding empirical research" (Arlinghaus 2005: 145). There remain few systematic 
Fig. 1. Map showing case study locations

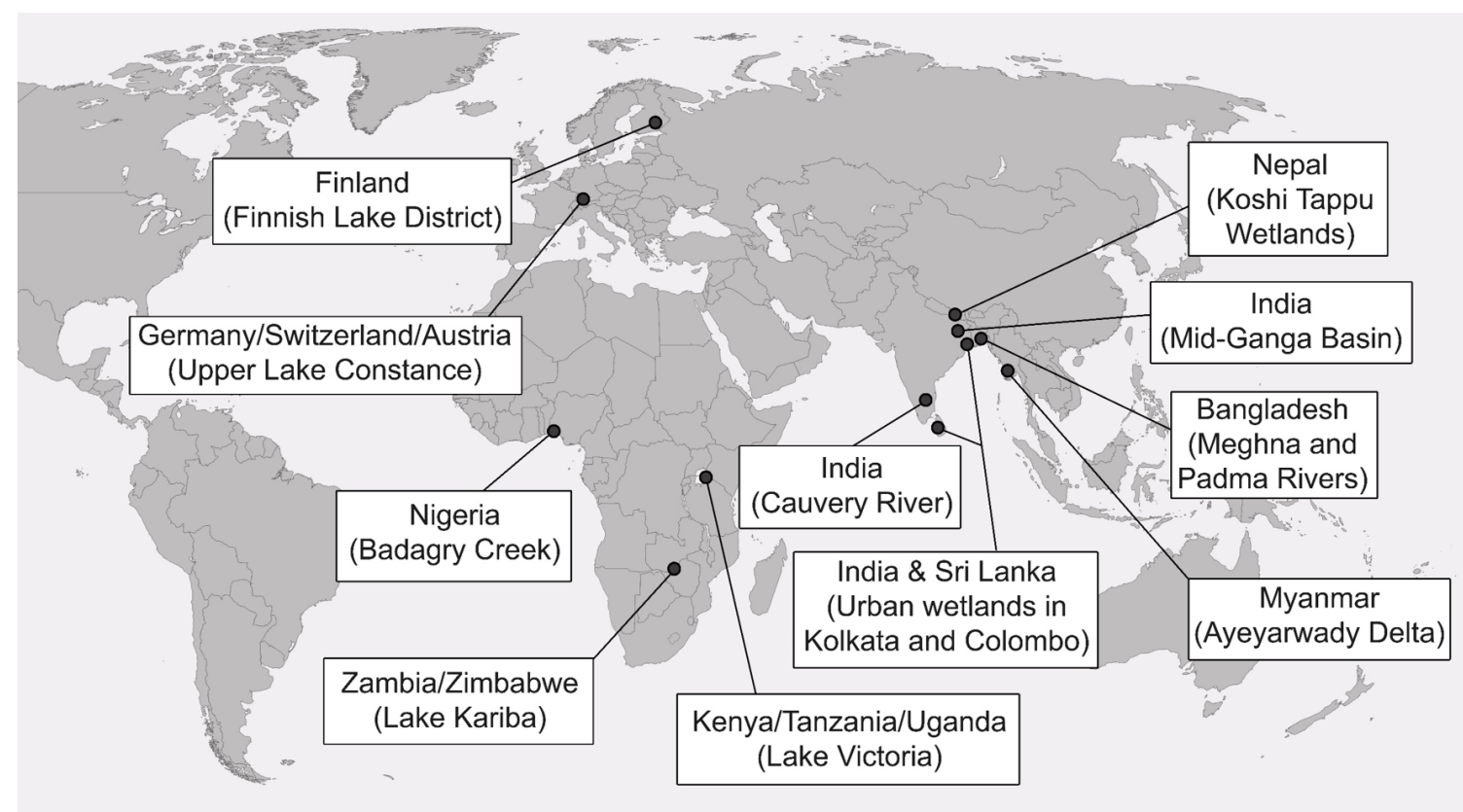

investigations that synthesize the details of fisheries' external conflicts, whose formation and impact are often poorly understood (Bennett et al. 2001). Intersectoral linkages have thus lacked dedicated research attention (for exceptions, see Arlinghaus 2005, Ratner et al. 2013, Lynch et al. 2016a, Nguyen et al. 2016). It forms a significant knowledge gap in the literature about the governance and use of fresh and brackish water fisheries resources.

Drawing from the authors' first-hand knowledge of various inland fishery settings around the globe presented in case study writing (see below) and in the wider literature, this article identifies four broad discursive mechanisms that can help reveal how policy decisions and practices are influenced in an intersectoral setting, i.e., system characterization, valuation, power relations, and vertical policy interaction (see below). These discursive mechanisms, which we define as the systems of thoughts that enable, construct, and direct human action and the worlds of which we come to know, are arrived at through an inductive, or a "bottom-up," approach rather than a deductive, prescriptionbased process (for examples of the latter approach, see VisserenHamakers 2015, Weitz et al. 2017). Our method of synthesis is most akin to grounded theory originally formulated by Glaser and Strauss, which can also offer a potentially suitable approach to the synthesis of secondary as well as primary data (Dixon et al. 2005). Through this, we were able to focus on generating a middle-range theoretical structure that can assist with explanations applying in a specified domain - in this instance, intersectoral interactions in fisheries (Noblit and Hare 1988). This process encouraged reflexivity and interpretation on the part of the researchers, and offered a means of limiting the number of cases to be included by way of theoretical saturation with emphasis being on conceptual robustness (Dixon et al. 2005). Logistically, participation of all authors in an e-book compilation on the same theme and their case-study chapters (see Song et al. 2017) provided an instrument through which to pool collective insights and synthesize lessons (see Appendix for a chapter summary). The compiled cases are by no means exhaustive, but are in sufficient number to be geographically and culturally diverse. They comprise 11 examples from three regions (six from South and Southeast Asia, three from Africa, and two from Europe) (see Fig. 1). They also feature a wide range of inland water settings, with four illustrating lake fisheries, three showcasing the river environment, two focusing on deltaic/coastal brackish waters, and two describing wetland/floodplain fisheries. We believe these cases collectively provide an adequate basis for developing an initial analytical model of intersectoral interactions concerning inland fisheries. A 2-day meeting attended by a subset of the authors was held in Kanchanaburi, Thailand, in August 2016, to consolidate the ideas (a report of the meeting is available at: http://toobigtoignore.net/wp-content/uploads/2016/12/TBTI_Thailandsympsium final.pdf).

Although each of the four mechanisms covers a key aspect of intersectoral relationships, this paper goes on to present them in a synthetic fashion to form an analytical model (see "Toward a synthesized understanding" below), which can guide exploration of the joined effects of intersectoral dynamics. In connection with The Rome declaration: ten steps to responsible inland fisheries (FAO and Michigan State University (MSU) 2016), the four aspects identified in this paper would thus form a research proposition that expands on the seventh step titled "Develop collaborative approaches to cross-sectoral integration in development agendas." Overall, the synthesis model provides a way of enhancing the governance of inland fisheries by explicitly recognizing and accounting for the relationships occurring between fisheries and other sectors. This remains an important but understudied area of research for enabling the elevation of fisheries' profile within the wider water-use discussion. 
Table 1. Summary of the key features of the four mechanisms that reveal and influence intersectoral relationships in the governance of inland fisheries

\begin{tabular}{|c|c|c|c|}
\hline $\begin{array}{l}\text { Features } \\
\text { System characterization }\end{array}$ & Valuation & Power relations & Vertical policy interaction \\
\hline \multicolumn{4}{|l|}{ Main function } \\
\hline $\begin{array}{l}\text { Attempts to explain the "who" } \\
\text { and "what" of the sectors involved } \\
\text { and their operational conditions } \\
\text { and social-ecological contexts }\end{array}$ & $\begin{array}{l}\text { Assesses intersectoral claims } \\
\text { according to a measurable rubric }\end{array}$ & $\begin{array}{l}\text { Probes the interactions to } \\
\text { understand why there may be } \\
\text { winners and losers }\end{array}$ & $\begin{array}{l}\text { Seeks explanations through global, } \\
\text { distant, supranational linkages }\end{array}$ \\
\hline \multicolumn{4}{|l|}{ Unique contribution } \\
\hline $\begin{array}{l}\text { Provides basic details about } \\
\text { governance workings of a } \\
\text { waterbody, also essential for } \\
\text { exploring other mechanisms }\end{array}$ & $\begin{array}{l}\text { Allows comparison of the varied } \\
\text { benefits of different sectors and } \\
\text { determining trade-offs }\end{array}$ & $\begin{array}{l}\text { Reveals deeper struggles and } \\
\text { motivations behind conflicts, } \\
\text { policy decisions, and governance } \\
\text { outcomes }\end{array}$ & $\begin{array}{l}\text { Focuses on extrasectoral, beyond- } \\
\text { waterbody influences that may } \\
\text { come to create a new playing } \\
\text { ground or overwhelm any local- } \\
\text { level cooperation }\end{array}$ \\
\hline \multicolumn{4}{|l|}{ Questions to ask } \\
\hline $\begin{array}{l}\text { - Which sectors are involved and } \\
\text { what are their interests and } \\
\text { activities? }\end{array}$ & $\begin{array}{l}\text { - Which values can be used to } \\
\text { represent the merits/benefits of } \\
\text { each sector involved? }\end{array}$ & $\begin{array}{l}\text { - How have situations of conflict, } \\
\text { inequity, or marginalization } \\
\text { among sectors come about and } \\
\text { persisted? }\end{array}$ & $\begin{array}{l}\text { - What are the prevailing global/ } \\
\text { regional trends that drive water and } \\
\text { land use? }\end{array}$ \\
\hline $\begin{array}{l}\text { - How are the sectors spatially and } \\
\text { functionally overlapping or } \\
\text { contradicting, and what impacts } \\
\text { are created? }\end{array}$ & $\begin{array}{l}\text { - How much are the sectors worth } \\
\text { quantitatively (e.g., monetarily) or } \\
\text { qualitatively (e.g., meaning- } \\
\text { making)? }\end{array}$ & $\begin{array}{l}\text { - What is their reach in terms of } \\
\text { lobbying, financing, and } \\
\text { networking? }\end{array}$ & $\begin{array}{l}\text { - How does the rationale for new } \\
\text { development get conveyed (e.g., } \\
\text { stories, images, propaganda)? }\end{array}$ \\
\hline $\begin{array}{l}\text { - What are the institutional scales, } \\
\text { structures, and rules that govern } \\
\text { individual sectors or in } \\
\text { coordination? }\end{array}$ & & $\begin{array}{l}\text { - Do win-win or synergistic } \\
\text { solutions work to empower less } \\
\text { powerful sectors or to serve an } \\
\text { apolitical prescription that } \\
\text { reinforces power imbalance? }\end{array}$ & $\begin{array}{l}\text { - Which global/regional proposal is } \\
\text { being embraced by which local } \\
\text { agents/sectors? }\end{array}$ \\
\hline \multicolumn{4}{|l|}{ Research methods } \\
\hline $\begin{array}{l}\text { Review of literature and spatial } \\
\text { data }^{\dagger} \text {; interviews and surveys }{ }^{\dagger} \text {; } \\
\text { archival research }^{\dagger} \text {; field-based } \\
\text { ethnographic research }{ }^{\dagger+} \text {; systemic } \\
\text { frameworks (e.g., governability } \\
\text { assessment })^{\dagger} \text {; institutional } \\
\text { analysis }^{\star} \text {; network analysis }{ }^{\dagger} \text {; GIS }\end{array}$ & $\begin{array}{l}\text { Review of literature and statistics }{ }^{\dagger} \text {; } \\
\text { household and landing surveys }{ }^{\dagger} ; \\
\text { cost-benefit analysis }{ }^{\dagger} \text {; contingent } \\
\text { valuation method }{ }^{\dagger} \text {; input-output } \\
\text { modeling }^{\star} \text {; socioeconomic and } \\
\text { livelihood analysis }{ }^{\star} \text {; narrative } \\
\text { approaches }^{\star}\end{array}$ & $\begin{array}{l}\text { Interviews and surveys }{ }^{\dagger} \text {; field- } \\
\text { based ethnographic research } \\
\text { thematic }^{\dagger} \text {; } \\
\text { analysis }\end{array}$ & $\begin{array}{l}\text { Review of published and gray } \\
\text { literature }{ }^{\dagger} \text { Interviews and surveys }{ }^{\dagger} \text {; } \\
\text { field-based ethnographic research }{ }^{\dagger+} \text {; } \\
\text { thematic analysis }^{\dagger} \text {; discourse } \\
\text { analysis }^{\star}\end{array}$ \\
\hline \multicolumn{4}{|l|}{ Limitations } \\
\hline $\begin{array}{l}\text { Generated insights may be } \\
\text { surficial and descriptive }\end{array}$ & $\begin{array}{l}\text { Measurement and reconciliation } \\
\text { of different types of values are } \\
\text { never perfect; the choice of } \\
\text { valuation methods itself is value- } \\
\text { laden, resulting in considerable } \\
\text { disagreement on how to value }\end{array}$ & $\begin{array}{l}\text { Information is often hidden, } \\
\text { latent, and guarded-not easy to } \\
\text { reveal, also not susceptible to } \\
\text { translate into policy prescriptions }\end{array}$ & $\begin{array}{l}\text { Identified issue can appear too } \\
\text { complex or overwhelming and } \\
\text { cause-and-effect not so clear, thus } \\
\text { may not seem readily possible to } \\
\text { intervene }\end{array}$ \\
\hline
\end{tabular}

\section{FOUR DISCURSIVE MECHANISMS THAT REVEAL AND INFLUENCE INTERSECTORAL RELATIONSHIPS}

\section{System characterization}

System characterization seeks a basic understanding of the governance history and the present regulatory setup (e.g., the legal mandate, the remit of different sectors, and the diverse management objectives) as well as the prevailing social-ecological conditions and cultural characteristics that preside over the waterbody (see Table 1 for a summary). It calls for a candid depiction of what can be observed in the interactions occurring at multiple scales and fora, concentrating on what is visible, overt, and therefore comparatively easy to assess and record. A vast range of possibilities exists for what should be described depending on the empirical reality of each place. Diagnostic tools such as the social-ecological system framework (McGinnis and
Ostrom 2014) and the governability assessment framework (Chuenpagdee and Jentoft 2013) may be helpful in organizing the wide-ranging descriptive details. Specific methods for capturing spatial dimensions (both qualitatively and quantitatively) would include ethnographic analysis (Herbert 2000), use of geographic information system (GIS) (Clarke 2001) and spatial pattern analysis (O'Sullivan and Unwin 2002). For understanding temporal changes, longitudinal studies (Lavrakas 2008) and archival techniques (Lewis-Beck et al. 2004) are available. In addition, important questions such as which sectors are present at a waterbody and to what extent, where each sector is positioned in the institutional structures and who they form coalitions with could be answered through stakeholder analysis (Grimble and Wellard 1997), institutional analysis (Kurian 2004), and/or discourse network analysis (Leifeld 2018). Such information 
details how conflicts or cooperation are manifested by tracing the positions, rationales, and demands of each sector that lead to friction and/or synergy and can foreground a description of more profound issues. Weitz et al. (2017: 171) argue that "we must consider who is involved in decision-making processes... Recognizing local knowledge and local stakeholders' rights and interests is especially important in situations where power relations are asymmetrical between institutions at different scales." (See "power relations" as a separate discursive mechanism, which we detail in a section below.)

Given that there is a diverse set of activities and actors operating in an increasingly complex and dynamic manner, a detailed portrayal and a purposeful framing of the sectors involved would be an essential starting point of any attempt to understand the workings of intersectoral linkages. Forming multiple layers of placed-based information, this research endeavor has, in fact, been widely adopted in existing studies, albeit with different foci. Examples from the case study chapters help illustrate the various aspects of this mechanism.

Mhlanga and Nyikahadzoi (2017), for instance, draw attention to the spatial and historical struggles among different sectors that operate Lake Kariba, two of which are competition for overlapping littoral space between fishery and tourism industries (such as houseboats and lodges) and controversies surrounding big game poaching, with fishing camps being accused of facilitating poachers' access into nearby wildlife protected areas. In both settings, physical and perceived aggravations are possible, wherein poachers allegedly make an illicit entry through fishing camps or fishers' presence can intrude into a holiday-maker's wilderness experience. The authors also report a case of postcolonial racial tension between the white-operated ring netbased kapenta (Limnothrissa miodon) fleets and black gillnet operators casting an historically ingrained consideration for the present-day understanding.

In Lake Victoria, Nunan and Onyango (2017) have highlighted the multiscale setup of intersectoral linkages. On the one hand, there are the community-level interactions that occur between village committees or occupational groups that are largely based on personal relationships and informal encounters. On the other hand, supranational cooperation is being encouraged through the Lake Victoria Basin Commission, which is tasked with the harmonization of policies and laws within the East African Community member countries for improving the collaborative management of transboundary natural resources, pollution, and environmental degradation in the basin. In this case, coordination at the national level appears key (although greatly lacking), as both the effectiveness of decentralization and of upward ministry involvement hinge on the sound oversight and financial capacity of the central government.

There are also intrasectoral interactions that can be instructive. Although fish is indeed the common denominator of all segments involved in fishery, various groups might hold opposing interests and construct different meanings for the fish and fisheries. In Bangladesh, Islam et al. (2017) catalogued cooperative and conflicting relationships that often simultaneously appear between fishery-related actors, such as fishers, fish entrepreneurs, microfinance nongovernmental organizations, law-enforcing agencies, and the local government in charge of administering the
Payment for Ecosystem Services scheme. The inter- and intrasectoral interactions most commonly observed in inland fisheries are listed in Table 2.

Table 2. List of external sectors that interact with inland fisheries and also internal groups that could be featured in an inland fishery (note: these are representative labels, thus not necessarily mutually exclusive, e.g., water quality overlaps with the concerns of multiple sectors, including fishing, domestic use, tourism, and nature conservation; there can be a subsistence component to all other fisheries sectors)

\begin{tabular}{ll}
\hline \hline Intersectoral (beyond fishery) & \\
- Hydropower generation & - Flood control and drainage \\
- Potable water and domestic & - Industrial use, including \\
use & mining \\
- Agriculture, silviculture, and & - Recreation and tourism \\
irrigation & \\
- Nature conservation and & - Shipping and transportation \\
animal rights & \\
Intrasectoral (within fishery) & \\
- Commercial fishery & - Recreational fishery \\
- Subsistence and indigenous & - Migrant fishery \\
fishery & \\
- Poaching/illegal fishery & - Aquaculture \\
- Fish trading and processing & - Marine fishery \\
\hline
\end{tabular}

\section{Valuation}

The valuation mechanism deals with assessing assigned values of different sectors. According to Brown (1984), assigned values refer to a benefit, worth, or merit that is given to an object. Assessed through a wide range of valuation techniques (see below), comparison of assigned values is about estimating how different sectors measure up in terms of the contributions they pose to the society. When different sectors' utilization of inland waters is deemed at odds with each other, which sector should receive developmental priority? Valuation of their merits is expected to assist in answering this question, thus offering a way to adjudicate intersectoral trade-offs. With an implicit assumption of a zerosum game, this approach ultimately seeks an instrumental explanation and has been given considerable attention in inland water resource research (e.g., Baran et al. 2007, Ziv et al. 2012).

Among the approaches developed to articulate and capture different kinds of values (e.g., sociocultural and ecological values), economic valuation has been the one most commonly pursued (see Grantham and Rudd 2015). The overall aim of this approach is that an enhanced understanding of the monetary value of inland fisheries (commercial, subsistence, and recreational activities) will reveal the extent of its true economic significance, which in many cases, has been simply buried and therefore ignored. Situating the valuation of fish and fisheries in the broader rubric of ecosystem services has also been touted as an effective strategy that highlights their essential connections to ecosystem functioning (e.g., Hoeinghaus et al. 2009). A comprehensive valuation, including incorporating the temporal or intergenerational dimension (e.g., through discount rates), is expected to bring more informed decision making in favor of inland fisheries and garner greater public support within the context of wider economic development and sustainable 
livelihoods. In this regard, Arlinghaus et al. (2002:273) have stated that, "for inland fisheries conservation as well as management, it is essential to provide a thorough economic evaluation of inland fisheries to defend the position of the sector per se against aquatic resource development schemes."

Several valuation results are indeed noteworthy. For example, de Graaf and Garibaldi (2014) estimate U.S.\$6.3 billion as the gross value added by the inland fisheries and aquaculture sector to the whole of Africa in 2011. In the Mekong delta alone, inland fisheries that combine riverine, reservoir, and aquaculture inland fisheries were valued at U.S.\$1.5 billion at the time of study (Barlow 2002). These aquatic resources are often regarded as most crucial to the poorest people for sustaining their income, livelihood, and nutritional wellbeing, but they can also be valuable to wealthier groups in society. In the Ayeyarwaddy region of Myanmar, a survey by Tezzo et al. (2017) reveals that the annual average price of "leasable fishery" (Innthugyis in the Burmese language) in 2014 was U.S.\$5,726 with a large majority of the 1,265 leases recorded in the region valued above U.S.\$1,000. Given that the average annual per capita income in Myanmar is estimated at U.S.\$1,105 (World Bank 2014), this result highlights the considerable value of fishery in the local context and its relevance as a prized asset.

In addition to economic values, there are other kinds of values that can be assessed and emphasized to more fully characterize inland fisheries. In fact, the greatest offering of many inland fisheries to society is perhaps found in their noneconomic contributions expressed through values that are nonmonetary and even not easily quantifiable. For instance, accurately capturing the scope of food security and nutritional benefits bestowed by inland fish and fisheries and the extent to which they contribute to people's livelihoods can be an important marker of their importance. Furthermore, inland fisheries are often a source and a carrier of experiential, identity, cultural, and place attachment values for those who participate, providing psychological, spiritual, and communal benefits (e.g., Close et al. 2002, Jackson et al. 2005). Arguably, these values do not only pertain to indigenous groups found in various pockets of the world, but are also experienced by numerous (and scattered) waterside residents and recreational fishers in the industrialized regions of North America and Europe (e.g., Hickley and Tompkins 1998, Kearney 2002). It is expected that such values will be of increasing relevance to larger segments of society as participation in recreational angling is growing in developing countries such as India (Bower et al. 2014). Most crucially, these humanistic values held by fishers and a fish-dependent populace that go beyond the instrumental purview can help set apart inland fisheries from other waterutilizing sectors, helping to advance different, and more diverse, arguments toward elevating the public perception and the political impetus for inland fisheries.

Valuation is, however, never an exact science. Conversion of the values into a format readily communicable and comparable is inherently unsatisfying, which is partially why values are not easily amenable to decision making. Arlinghaus et al. (2002: 271) have admitted that the "benefits created by inland fisheries are difficult to group, quantify and evaluate." Fortunately, different valuation procedures are available for helping to capture and analyze the values within and across the different sectors. More conventional quantification techniques include cost-benefit analysis, contingent valuation method, economic impact assessment methods such as using the gross value of fish landings based on market prices (e.g., Neiland and Béné 2006) and various modeling approaches (e.g., Orr et al. 2012). There has also been an increasing interest in using fish consumption data based on agricultural household surveys (e.g., Belton et al. 2011), nonmonetary ranking techniques such as damage schedules (e.g., Song and Chuenpagdee 2013), socioeconomic or livelihood analysis (e.g., Béné and Neiland 2003), and even narrative approaches that center on individual, community, and societal wellbeing (e.g., Song 2018). Despite the significant challenges noted above, the many values of inland fisheries and an active interest in confirming them through a range of valuation techniques present optimism for a breakthrough in clarifying and enhancing the intersectoral position of inland fisheries (Cowx and Portocarrero Aya 2011, Cooke et al. 2013, Lynch et al. 2017).

\section{Power relations}

This aspect privileges the role of power in addressing the intersectoral governance of an aquatic system. Involving multiple sectors with diverse interests and overlapping administrative boundaries, especially under the assumption of resource limitation and zero-sum situation, means that there can arise uneven power relations that undergird a particular dynamic between water sectors, including the marginalization of inland fisheries.

Power is one of the central topics in social sciences and governance research and is advanced with many varied meanings (Haugaard and Clegg 2009, Morrison et al. 2017). A conventional way to define power is by referring to the capacities or abilities to shape context or conduct of others (Boonstra 2016). By applying various indicators of power, such as financial resources, infrastructure, access to natural resources, reputation, social connections, information, and technology, each sectoral interest would work to influence decision making about intersectoral relationships and the structural contexts that condition it. On the one hand, power is about winners and losers, and about how tradeoffs are determined or maintained between the winning and losing sectors. Power can be used to widen or intensify existing disparities. It can also be manifested in more insidious forms such as patronage, indebtedness, corruption, and nepotism. On the other hand, power can be a productive force that represents potential for change and creation of enhanced opportunities (Jentoft 2007). In this regard, power is about empowermentachieving a fairer representation of a disadvantaged group, sharing responsibilities through comanagement or decentralization, and widening the knowledge base to include less dominant forms of understanding such as local traditional knowledge. Jentoft (2007: 431) argues that "we should not always think of power as zero-sum, that the empowerment of some necessarily implies the disempowerment of someone else... Relationships of power might then be more than the sum of parts. Power is sometimes strengthened by being shared." In the same vein, though much rarer in practice, so-called "win-win" scenarios (see Beard et al. 2011, Lynch et al. 2016a) can be regarded as promoting this synergistic function of power, insofar as they are conceived in recognition of power dynamics and do not simply serve an apolitical and neutral prescription akin to a straightforward technical-administrative solution, e.g., a "panacea." 
The trend of inland fisheries research reflects the broader domain of fisheries and water resource research, in which power remains an undertreated topic (Visseren-Hamakers 2015, Weitz et al. 2017). Even in studies that address power, prioritization of its specific facets, such as conflict, inequity, and marginalization, are often needed for research tractability (e.g., Bennett et al. 2001, Nguyen-Khoa and Smith 2004, Arlinghaus 2005). Nevertheless, this is undoubtedly a crucial topic of investigation and forms an essential make-up of intersectoral linkages. Salmi and Sipponen (2017) analyzed the complex power relations that have occurred in vendace (Coregonus albula) fisheries in Finnish lakes, in which both intrasectoral and intersectoral power dynamics are present. In the early 1990s, water owners of private lakes had used their legally sanctioned management authority to refuse the granting of commercial fishing permits despite scientific reports suggesting that commercial fishery using small pair trawling and seine netting does not jeopardize the stock health. The authors observed that local water owners' opposition to commercial fishing is tied to their will to stamp positional clout in local-level fisheries management and at the same time advance their recreational fishing opportunities. More recently, an increasing concern of nature conservationists for the bycatch of endangered Saimaa ringed seal (Pusa hispida saimensis) by commercial and recreational fishing had successfully convinced water owners and government authorities to institute a system of seasonal fishing bans. Although the fishing ban applied equally to both commercial and recreational fishing groups, a heavier impact was on the approximately 60 commercial fishers located in the habitat of the Saimaa ringed seal who became deprived of an important income source, compared with about 400,000 recreational fishers in the area. According to the authors, the lack of consideration of the livelihood aspect for commercial fishers is another reflection of the weaker lobbying power and political standing of the commercial lake fishery in relation to the recreational sector. It also hints at the lower priority of natural resource utilization vis-à-vis nature conservation in decisions being made about waterbody use.

Asymmetrical power relations do not, however, always result in visible conflict and social disorder (Lukes 1974, Gaventa 1980). A seemingly peaceful and consensual situation may in fact be harboring entrenched inequality, domination, and deprivation in which the sense of powerlessness within marginalized sectors is prevalent and self-perpetuating. This reinforces the fact that an investigation of power is all the more crucial in a multistakeholder, intersectoral setting, in which large power differentials may be operating. In many inland fisheries, both in developed and developing regions, such covert power dynamics might be what is happening. Dedicated approaches drawing on political ecology or political economy (e.g., see Derman and Ferguson 1995, Sneddon 2007, Béné et al. 2009, Nayak et al. 2016, Sneddon and Fox 2012) will be helpful. Yet, more general approaches using qualitative methods such as field-based ethnographic research and discourse analysis of policy documents would also represent a useful contribution.

\section{Vertical policy interaction}

Whereas the previous mechanisms tend to focus on horizontal interactions taking place in proximate surroundings at the level of a watershed, the final inquiry seeks to examine high-level societal aspirations and discourses that exert influence on inland fisheries. These are seen as external drivers that go beyond geographical confines of a defined waterbody, thus escaping the immediate control of local or national actors, and can strongly motivate the objectives and priorities for development and management of inland waters (Lynch et al. 2016a). Similarly, the pertinent literature has questioned the (typical) horizontal scope of water resource analysis by recognizing that barriers and solutions may lie in the broader political economy (Weitz et al. 2017). Such vertical, multiscalar dynamics are an increasingly important consideration in the current era characterized by economic globalization, supranational coordination, and climate change. Concepts such as cross-scale linkages (Berkes 2002), earth system governance (Biermann 2007), and telecoupling (Liu et al. 2013) all elaborate on general theories of ways to ensure environmental and natural resource sustainability in light of these "distant" implications.

Inland fisheries are no exception to these expanding governance processes. Ideas, resources, finances, people, and goods can all descend upon the sites of fisheries affecting the trajectory of intersectoral interactions. Synergistic and balanced relationships that may have existed between fisheries and other sectors could start to tip in favor of a new dynamic fed by a development of a particular discursive undercurrent. The case of an urban wetland fishery in Kolkata offers an instructive example in this regard, in which the fishery sector is put under growing pressure from a wider development agenda that has upset local-level symbiosis (Hettiarachchi and Morrison 2017). In the early 20th century, in response to wastewater and sewage discharge from an expanding city, the dwellers of the East Kolkata Wetlands skillfully devised a vast network of freshwater ponds to transform runoff into a source of nutrients for aquaculture. This had marked a symbiotic relationship between urban water treatment needs and wetland livelihoods, which was exemplified by the annual production of $8,000 \mathrm{t}$ of fish combined with a daily intake of $0.7-1.0$ million $\mathrm{m}^{3}$ of wastewater in 2010. Additionally, it is estimated that the wetland provided ecosystem services of carbon sequestration and recreation, each valued at 53 million and 43 million rupees per annum (ca. U.S.\$0.8 and 0.6 million). However, spurred by the procapital economic restructuring in India during the 1980s, the wetland system came under intense urbanization pressure. Speculative real-estate investment and the inflow of international finance capital ensued, and as a result, nearly $20 \%$ of the wetland was reclaimed for real-estate purposes by 2003 , with more unaccounted conversion suspected in recent decades (Hettiarachchi and Morrison 2017). Along with the reduction of the wetland area, ensuing excessive siltation deteriorated water quality and rendered fish ponds unusable.

Likewise, in Lake Constance in Europe, Baer et al. (2017) described how an internationally coordinated agreement on improving water quality can influence the image of a lake such that water quality quickly establishes itself as the primary concern for the management of a waterbody. The societal narrative toward "clean" water can work to benefit those sectors that favor an oligotrophic condition with clear-blue water while overshadowing others that prefer a more mesotrophic state such as a commercial capture fishery. Baer at al. (2017: 12) write, "Having played a central role in lake management and decision-making in the past, in particular during the eutrophic phase, Upper Lake Constance fisheries now find themselves second in terms of socio-political 
importance compared to environmental protection, tourism, water quality and outdoor recreation. The lake condition that would constitute an optimal solution from a fisheries perspective (i.e., $\mathrm{P}$ at about $10-12 \mu \mathrm{g} \cdot \mathrm{L}^{-1}$ ) is anathema to prevailing societal concerns, including those of environmental protection organizations, and contravenes current interpretation of environmental policy such as the EU Water Framework Directive."

The aspiration toward developing water resources of major rivers for hydropower generation is another case in point (Bakker 1999, Lebel et al. 2005, Winemiller et al. 2016). In the Mekong River basin, large-scale hydropower development powered by big dams is a dominant and long-running regional theme that has garnered the strongest political and financial support (Greacen and Palettu 2007). The formation of this shared vision is said to stem from the Cold War era, in which U.S., Soviet, and Chinese planners all imagined a similar future for the Mekong, and has been, over time, heavily promoted by foreign donors and international financial organizations. With Laos aspiring to be the hydroelectric "battery of Asia," for example, the existential threat that accelerated hydro-development poses to fisheries and fisherybased livelihoods in the region is real and looming (Baran and Myschowoda 2009, Vaidyanathan 2011). By the same token, inland fisheries can, however, also look to rally around a different discursive ideal. The "food security" argument (e.g., Béné et al. 2016, McIntyre et al. 2016) or the "local food movement" buttressed on healthy food production in an environmentally sustainable and socially responsible manner (e.g., Nelson et al. 2013) may be among some of the strategic avenues to which inland fisheries can attach themselves with the assistance of nongovernmental organizations and other civil society partners.

Alternatively phrased as "global drivers" (Nayak and Berkes 2014, Lynch et al. 2016a) or "external inputs" (Nguyen et al. 2016), the vertical interactions that embody overarching political economy may thus dictate the national or local policy agenda, providing a raison d'être for the use of inland waters and subsequently shape public opinion of involved sectors. Understanding intersectoral interactions would therefore require a broadening of the research scope to see these multiscale connections as integral to the process of governing inland fisheries.

\section{TOWARD A SYNTHESIZED UNDERSTANDING}

Each of these four mechanisms forms an important research undertaking on its own, as indicated above. Yet, they are also pieces of a bigger governance puzzle, with each putting unique emphasis on intersectoral interaction (as summarized in Table 1). Their thematic connection is an important consideration and leads to synthesized insights. First, the broad-based characterization of the intersectoral relationships is basic to all other inquiries. Some understanding of the involved sectorstheir activities, management structure, beneficiaries, and demands on water and space — would be required to establish their relevance in terms of sectoral overlap and influence (see Fig. 2., arrow a). Next, estimated values of the sectors can be used to shift the power dynamic by empowering sectors such as fisheries in resource allocation decisions (Fig. 2, arrow b). In one example reported by Navrud (2001), the Norwegian Fishing and Hunting Association was able to successfully increase government funding for deacidifying salmon rivers and brown trout lakes in southern Norway by using estimated recreational and nonuse values of fish, which demonstrated social benefits that are 1.2-4.4 times the costs of liming and restocking. Yet, this should remain a cautious proposition, because, as noted from the history of hydropower development in the Mekong, favorable valuation results may still be ineffective in shifting power relations if power imbalance between sectors is too large. It follows that valuation itself can be influenced and even distorted by the politics (Fig. 2, arrow c). Valuation numbers may differ depending on which method is employed (e.g., whether cost-benefit analysis or multicriteria evaluation) or which discount rate is used. The question, according to Martínez-Alier (2001: 727), is "who has then the power to impose a particular language of valuation?" Importance given to the different values can depend on the "outcomes of the conflicts," as those who surface as "winners" would be at an advantage to dictate the terms of valuation.

Fig. 2. Four broad discursive mechanisms for understanding intersectoral dynamics in the governance of inland fisheries and how they are linked to each other (solid arrow: shape; dotted arrow: inform). (a) Characterization of intersectoral presence and linkages forms the basis and informs all other inquiries; (b) Valuation results can empower previously neglected sectors and help alter power relations; (c) Power and politics influence the choice, interpretation, and promotion of values and valuation methods; (d, f) High-level discourses can profoundly affect sector prioritization and value alignment; $(e, g)$ Waterbody- and watershed-level empirical cases of valuation and power relationships can shape global discourses

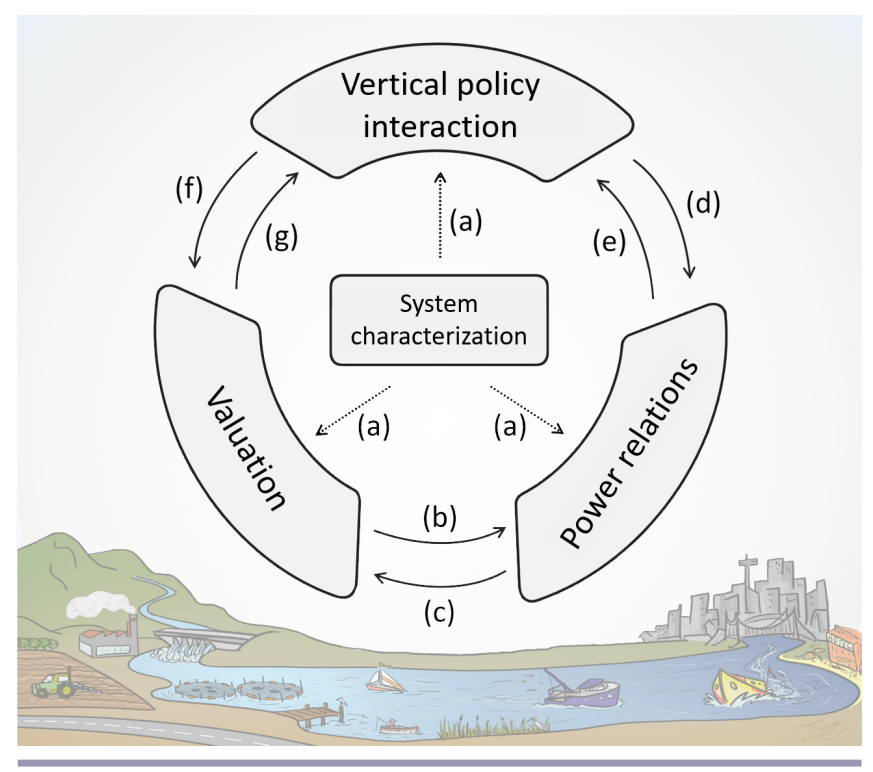

Probing further, vertical policy interaction will affect the intersectoral power relations subtly but forcefully, raising the legitimacy of the sectors that align with the prevailing paradigm while marginalizing others that do not (Fig. 2, arrow d). Likewise, the discourses can also reveal which types of values are prioritized and why, and dictate how they are to be weighed (Fig. 2, arrow f). Although indigenous and cultural values are being increasingly discussed in management contexts (e.g., Jackson 2006, Chan et 
al. 2011), economic values will likely remain the basis of modus operandi given the dominant ideological orientation of "economic man" in governance processes (Söderbaum 1999). Reciprocally, the high-level discourses would also be shaped by local, watershed, or national-level experiences (Fig. 2, arrow e). Capable sectors on-the-ground may deliberately enlist (or dismiss) support of certain discourses, thereby reinforcing or weakening the potency of affected discourses (e.g., irrigated agriculture championing the "food security" objective, but not "wetland conservation"). Unlike the top-down influences, the local-toglobal processes may be more difficult to detect and analyze because impacts on global commons are felt more slowly and cumulatively and the cause-effect relationships tend to be diffuse and complex (Nayak and Berkes 2014). Still, well-publicized cases of environmentally destructive practices of brackish shrimp farming in tropical mangrove settings have, for instance, led to changing consumer preferences, as reflected in certification schemes and consumer purchasing behavior, and have contributed to shaping global awareness about the sustainableuse patterns of inland water resources (Oosterveer 2006). Moreover, many recent efforts to recognize and diversify the values of inland fisheries by academia, nongovernmental organizations, and global institutions demonstrate the potential of empirical work to inspire a "grand" discourse (see Baran et al. 2007, Taylor et al. 2016, FAO and MSU 2016) (Fig. 2, arrow g).

Thus, not only does each mechanism provide a discrete lens to reveal the rationale for policy actions that affect inland fisheries, they can also work in a joined-up way to explore how policy trends are shaped and influenced. In addition to being a desirable undertaking, examining inland fisheries in a synthetic manner may in fact be a necessity. Performed alone, the valuation task may run the risk of being ineffective, if the estimated values of inland fisheries still fall short of what is needed to claim its renewed importance relative to other competing sectors. In such a case, a more qualitative approach that deconstructs why and how the value differences come to be established and what can tip the balance in terms of win-win solutions or new discursive ideals could contribute to constructing a stronger argument for inland fisheries. In the same vein, merely providing a critical analysis of power relations may be less than satisfying when it comes to making policy suggestions. A possibility of quantifying important details through well-structured system characterization and/or valuation should be sought to help translate the lessons into more accessible terms.

\section{CONCLUDING REMARKS}

Synthesizing empirical experiences documented in case study writing and in the literature, this paper explains an heuristic model aimed at enhancing the governance of inland fisheries by recognizing and accounting for the relationships occurring with other water-based sectors. Simply put, inland fisheries do not work as an isolated governance entity, perhaps even more so than marine fisheries (Hilborn et al. 2003, Cooke et al. 2014). Whereas the fishing populace and fisheries managers would be directly responsible for managing fisheries, other sectoral interests play an oblique yet momentous role in determining its fate. In promoting another view of development, other sectoral interests may be advancing a certain valuation logic that inevitably trivializes fisheries. In doing so, they could also be exerting resources to win local and wider public support, framing debates to sway interpretations of scientific data and media reports, siding with particular global narratives and funding bodies, and offering status quo-driven win-win solutions. All this (and more in the form a poor design, a weak multistakeholder process, and operational inefficiency) has been observed in the case of the Pak Mun Dam in northeast Thailand, for instance, where social strife to defend and restore fisheries-dependent livelihoods has been equally rife since the approval of the dam in 1989 and is ongoing to this day, prompting Foran and Manorom (2009) to call it "perpetually contested." This raises the question of whether the process would have been any easier and better decisions derived if the above lessons were sought and more readily available from the outset.

In the end, despite the augmented research endeavor and betterinformed political conversations, inland fisheries might still garner low priority in water decision making. Promoting sustainability and resilience of inland fish and fisheries could, therefore, continue to face an uphill task. The exclusion of inland fisheries in preference of a sole focus on the marine domain in the 2030 Sustainable Development Goals is a stark reminder that inland fisheries occupy a peripheral position in the wider sustainability discussion. Nevertheless, tangible and important benefits of inland fisheries do occur around the world and are not to be overlooked. Viewing policy outcomes and research initiatives of inland fisheries through intersectoral lenses can help stimulate more balanced guidance for streamlined water development (e.g., using the approach taken here as a start). We submit that failure to act upon the connected effects of intersectoral influences risks further dissipation of the livelihood and biodiversity functions of inland waterbodies, putting millions of fishers and waterside communities' crucial dependence worldwide in jeopardy.

Responses to this article can be read online at: http://www.ecologyandsociety.org/issues/responses. php/10076

\section{Acknowledgments:}

This work was supported by the Social Sciences and Humanities Research Council-funded project, Too Big to Ignore: Global Partnership for Small-Scale Fisheries Research [895-2011-1011]. It also contributes to the CGIAR Research Program on Fish AgriFood Systems (FISH). The authors thank Ruby Grantham, Tiffany Morrison, and an anonymous reviewer for constructive and helpful comments on earlier versions of the manuscript.

\section{LITERATURE CITED}

Adeyemo, O. K. 2003. Consequences of pollution and degradation of Nigerian aquatic environment on fisheries resources. The Environmentalist 23:297-306. http://dx.doi. org/10.1023/B:ENVR.0000031357.89548.fb

Allan, J. D., R. Abell, Z. Hogan, C. Revenga, B. W. Taylor, R. L. Welcomme, and K. Winemiller. 2005. Overfishing of inland waters. BioScience 55:1041-1051. http://dx.doi.org/10.1641/0006-3568 (2005)055[1041:OOIW]2.0.CO;2 
Arlinghaus, R. 2005. A conceptual framework to identify and understand conflicts in recreational fisheries systems, with implications for sustainable management. Aquatic Resources, Culture and Development 1:145-174.

Arlinghaus, R., T. Mehner, and I. G. Cowx. 2002. Reconciling traditional inland fisheries management and sustainability in industrialized countries, with emphasis on Europe. Fish and Fisheries 3:261-316. http://dx.doi.org/10.1046/j.1467-2979.2002.00102. $\underline{\mathrm{x}}$

Baer, J., R. Eckmann, R. Rösch, R. Arlinghaus, and A. Brinker. 2017. Managing Upper Lake Constance fishery in a multi-sector policy landscape: beneficiary and victim of a century of anthropogenic trophic change. Pages 32-47 in A. M. Song, S. D. Bower, P. Onyango, S. J. Cooke, and R. Chuenpagdee, editors. Inter-sectoral governance of inland fisheries. Too Big To IgnoreWorldFish, St. John's, Newfoundland, Canada.

Bakker, K. 1999. The politics of hydropower: developing the Mekong. Political Geography 18:209-232. http://dx.doi. org/10.1016/S0962-6298(98)00085-7

Baran E., T. Jantunen, and C. K. Chong. 2007. Values of inland fisheries in the Mekong River Basin. WorldFish Center, Phnom Penh, Cambodia.

Baran, E., and C. Myschowoda. 2009. Dams and fisheries in the Mekong Basin. Aquatic Ecosystem Health and Management 12:227-234. http://dx.doi.org/10.1080/14634980903149902

Barlow, C. 2002. Size and value of the fishery in the LMB. Pages 13-14 in S. Sverdrup-Jensen, editor. Fisheries in the lower Mekong Basin: status and perspectives. MRC Technical Paper 6. Mekong River Commission, Phnom Penh, Cambodia.

Bartley, D. M., G. J. de Graaf, J. Valbo-Jørgensen, and G. Marmulla. 2015. Inland capture fisheries: status and data issues. Fisheries Management and Ecology 22:71-77. http://dx.doi. org/10.1111/fme.12104

Beard T. D., R. Arlinghaus, S. J. Cooke, P. B. McIntyre, S. De Silva, D. Bartley, et al. 2011. Ecosystem approach to inland fisheries: research needs and implementation strategies. Biological Letters 23:481-483. http://dx.doi.org/10.1098/rsbl.2011.0046

Belton, B., M. Karim, S. Thilsted, K. Mursed-E-Jaran, W. Collis, and M. Phillips. 2011. Review of aquaculture and fish consumption in Bangladesh. The WorldFish Center, Penang, Malaysia.

Béné, C. 2003. When fishery rhymes with poverty: a first step beyond the old paradigm on poverty in small-scale fisheries. World Development 31:949-975. http://dx.doi.org/10.1016/S0305-750X (03)00045-7

Béné, C., R. Arthur, H. Norbury, E. H. Allison, M. Beveridged, S. Bush, L. Campling, W. Leschen, D. Little, D. Squires, S. H. Thilsted, M. Troell, and M. Williams. 2016. Contribution of fisheries and aquaculture to food security and poverty reduction: assessing the current evidence. World Development 79:177-196. http://dx.doi.org/10.1016/j.worlddev.2015.11.007

Béné, C., E. Belal, M. O. Baba, S. Ovie, A. Raji, I. Malasha, et al. 2009. Power struggle, dispute and alliance over local resources: analyzing 'democratic' decentralization of natural resource through the lenses of Africa inland fisheries. World Development 37:1935-1950. http://dx.doi.org/10.1016/j.worlddev.2009.05.003

Béné, C., and A. E. Neiland. 2003. Valuing Africa's inland fisheries: overview of current methodologies with an emphasis on livelihood analysis. NAGA, WorldFish Center Quarterly 26(3):1821 .

Bennett, E., A. Neiland, E. Anang, P. Bannerman, A. A. Rahman, S. Huq, S. Bhuiya, M. Day, M. Fulford-Gardiner, and W. Clerveaux. 2001. Towards a better understanding of conflict management in tropical fisheries: evidence from Ghana, Bangladesh and the Caribbean. Marine Policy 25:365-376. http:// dx.doi.org/10.1016/S0308-597X(01)00022-7

Berkes, F. 2002. Cross-scale institutional linkages: perspectives from the bottom up. Pages 293-321 in E. Ostrom, T. Dietz, N. Dolsak, P. C. Stern, S. Stonich, and E. U. Weber, editors. The drama of the commons. National Academy Press, Washington D. C., USA.

Biermann, F. 2007. 'Earth system governance' as a crosscutting theme of global change research. Global Environmental Change 17:326-337. http://dx.doi.org/10.1016/j.gloenvcha.2006.11.010

Boonstra, W. J. 2016. Conceptualizing power to study socialecological interactions. Ecology and Society 21(1): 21. http://dx. doi.org/10.5751/ES-07966-210121

Bower, S. D., V. M. Nguyen, A. J. Danylchuk, T. D. Beard, Jr., and S. J. Cooke. 2014. Inter-sectoral conflict and recreational fisheries of the developing world: opportunities and challenges for co-operation. Pages 88-97 in P. McConney, R. Medeiros, and M. Pena, editors. Enhancing stewardship in small-scale fisheries: practices and perspectives. Too Big To Ignore and CERMES, The University of the West Indies, Cave Hill Campus, Barbados.

Brönmark, C., and L. A. Hansson. 2002. Environmental issues in lakes and ponds: current state and perspectives. Environmental Conservation 29:290-306. http://dx.doi.org/10.1017/S0376892902000218

Brown, T. C. 1984. The concept of value in resource allocation. Land Economics 60:231-246. http://dx.doi.org/10.2307/3146184

Brummett, R. E., M. C. M. Beveridge, and I. G. Cowx. 2013. Functional aquatic ecosystems, inland fisheries and the Millennium Development Goals. Fish and Fisheries 14:312-324. http://dx.doi.org/10.1111/j.1467-2979.2012.00470.x

Chan, K. M. A., J. Goldstein, T. Satterfield, N. Hannahs, K. Kikiloi, R. Naidoo, et al. 2011. Cultural services and non-use values. Pages 206-228 in P. Kareiva, H. Tallis, T. H. Ricketts, G. C. Daily, and S. Polasky,eds. Natural capital: theory and practice of mapping ecosystem services. Oxford University Press, Oxford, UK. http://dx.doi.org/10.1093/acprof:oso/9780199588992.003.0012

Chuenpagdee, R., and S. Jentoft. 2013. Assessing governability -what's next. Pages 335-349 in M. Bavinck, R. Chuenpagdee, S. Jentoft, and J. Kooiman, editors. Governability of fisheries and aquaculture: theory and applications. Springer, Dordrecht, The Netherlands. http://dx.doi.org/10.1007/978-94-007-6107-0 18

Clarke, K. C. 2001. Getting started with geographic information systems. Third edition. Prentice Hall, Upper Saddle River, New Jersey, USA. 
Close, D. A., M. S. Fitzpatrick, and H. W. Li. 2002. The ecological and cultural importance of a species at risk of extinction, Pacific lamprey. Fisheries 27:19-25. http://dx.doi.org/10.1577/1548-8446 (2002)027<0019:TEACIO>2.0.CO;2

Cooke, S. J., and I. G. Cowx, I.G. 2004. The role of recreational fishing in global fish crises. BioScience 54:857-859. http://dx.doi. org/10.1641/0006-3568(2004)054[0857:TRORFI]2.0.CO;2

Cooke, S. J., N. W. R. Lapointe, E. G. Martins, J. D. Thiem, G. D. Raby, M. K. Taylor, T. D. Beard, and I. G. Cowx. 2013. Failure to engage the public in issues related to inland fishes and fisheries: strategies for building public and political will to promote meaningful conservation. Journal of Fish Biology 83:997-1018. http://dx.doi.org/https://doi.org/10.1111/jfb.12222

Cooke, S. J., R. Arlinghaus, D. M. Bartley, T. D. Beard, I. G. Cowx, T. E. Essington, O. P. Jensen, A. Lynch, W. W. Taylor, and R. Watson. 2014. Where the waters meet: sharing ideas and experiences between inland and marine realms to promote sustainable fisheries management. Canadian Journal of Fisheries and Aquatic Sciences 71:1593-1601. http://dx.doi.org/10.1139/ cjfas-2014-0176

Cooke, S. J., E. H. Allison, T. D. Beard Jr., R. Arlinghaus, A. H. Arthington, D. M. Bartley, I. G. Cowx, C. Fuentevilla, N. J. Leonard, K. Lorenzen, A. J. Lynch, V. M. Nguyen, S. -J. Youn, W. W. Taylor, and R. L. Welcomme, R.L. 2016. On the sustainability of inland fisheries: finding a future for the forgotten. Ambio 45:753-764. http://dx.doi.org/10.1007/ s13280-016-0787-4

Cowx, I. G. 2002. Principles and approaches to the management of lake and reservoir fisheries. Pages 376-393 in I. G. Cowx, editor. Management and ecology of lake and reservoir fisheries. Fishing New Books, Oxford, UK. http://dx.doi.org/10.1002/9780470995679. $\underline{\operatorname{ch} 31}$

Cowx, I. G., and M. Portocarrero Aya. 2011. Paradigm shifts in fish conservation: moving to the ecosystem services concept. Journal of Fish Biology 79:1663-1680. http://dx.doi.org/10.1111/ j.1095-8649.2011.03144.X

Cowx, I. G., R. Arlinghaus, and S. J. Cooke. 2010. Harmonising recreational fisheries and conservation objectives for aquatic biodiversity in inland waters. Journal of Fish Biology 76:2194 2215. http://dx.doi.org/10.1111/j.1095-8649.2010.02686.x

Craig, J. F., A. S. Halls, J. J. F. Barr, and C. W. Bean. 2004. The Bangladesh floodplain fisheries. Fisheries Research 66:271-286. http://dx.doi.org/10.1016/S0165-7836(03)00196-6

Craviari, T., J. M. Pettifor, T. D. Thacher, C. Meisner, J. Arnaud, and P. R. Fischer. 2008. Rickets: an overview and future directions, with special reference to Bangladesh. Journal of Health, Population and Nutrition 26:112-121.

de Graaf, G., and L. Garibaldi. 2014. The value of African fisheries. FAO Fisheries and Aquaculture Circular. No. 1093. Food and Agriculture Organization (FAO), Rome, Italy.

Derman, B., and A. Ferguson. 1995. Human rights, environment, and development: the dispossession of fishing communities on Lake Malawi. Human Ecology 23:125-142. http://dx.doi. org/10.1007/BF01191646
Dixon-Woods, M., S. Agarwal, D. Jones, B. Young, and A. Sutton. 2005. Synthesising qualitative and quantitative evidence: a review of possible methods. Journal of Health Services Research and Policy 10:45-53. http://dx.doi.org/10.1177/135581960501000110

Dudgeon, D., A. H. Arthington, M. O. Gessner, Z. -I. Kawabata, D. J. Knowler, C. Lévêque, R. J. Naiman, A. -H. Prieur-Richard, D. Soto, M. L. J. Stiassny, C. A. Sullivan. 2006. Freshwater biodiversity: importance, threats, status and conservation challenges. Biological Reviews 81:163-182. http://dx.doi. org/10.1017/S1464793105006950

Dugan, P., A. Delaporte, N. Andrew, M. O'Keefe, and R. Welcomme. 2010. Blue harvest: inland fisheries as an ecosystem service. WorldFish Center, Penang, Malaysia; United Nations Environment Programme, Nairobi, Kenya.

Ficke, A. D., C. A. Myrick, and L. J. Hansen. 2007. Potential impacts of global climate change on freshwater fisheries. Reviews in Fish Biology and Fisheries 17:581-613. http://dx.doi. org/10.1007/s11160-007-9059-5

Food and Agriculture Organization (FAO). 1997. Inland fisheries. FAO Technical Guidelines for Responsible Fisheries 6. FAO, Rome, Italy.

Food and Agriculture Organization (FAO). 2010. State of world fisheries and aquaculture. FAO, Rome, Italy.

Food and Agriculture Organization (FAO) and Michigan State University (MSU). 2016. The Rome declaration: ten steps to responsible inland fisheries. FAO, Rome, Italy.

Foran, T., and K. Manorom. 2009. Pak Mun dam: perpetually contested. Pages 55-80 in F. Molle, T. Foran, and M. Kakonen, editors. Contested waterscapes in the Mekong region: hydropower, livelihoods and governance. Earthscan, London, UK.

Gaventa, J. 1980. Power and powerlessness. University of Illinois Press, Urbana, Illinois, USA.

Grantham, R. W., and M. A. Rudd. 2015. Current status and future needs of economics research of inland fisheries. Fisheries Management and Ecology 22:458-471. http://dx.doi.org/10.1111/ fme. 12144

Greacen, C., and A. Palettu. 2007. Electricity sector planning and hydropower in the Mekong Region. Pages 93-125 in L. Lebel, J. Dore, R. Daniel, and Y. S. Koma, editors. Democratizing water governance in the Mekong Region. Mekong Press, Chiang Mai, Thailand.

Grimble, R., and K. Wellard. 1997. Stakeholder methodologies in natural resource management: a review of principles, contexts, experiences and opportunities. Agricultural systems 55:173-193. http://dx.doi.org/10.1016/S0308-521X(97)00006-1

Haugaard, M., and S. R. Clegg. 2009. Introduction: why power is the central concept of the social sciences. Pages 1-24 in S. R. Clegg, and M. Haugaard, editors. The SAGE handbook of power. Sage Publications, London, UK.

Herbert, S. 2000. For ethnography. Progress in Human Geography 24:550-568. http://dx.doi.org/10.1191/030913200100189102

Hettiarachchi, M., and T. H. Morrison. 2017. A tale of two cities: similar ecologies and diverging governance of urban fisheries in 
Kolkata and Colombo. Pages 58-70 in A. M. Song, S. D. Bower, P. Onyango, S. J. Cooke, and R. Chuenpagdee, editors. Intersectoral governance of inland fisheries. Too Big To IgnoreWorldFish, St. John's, Newfoundland, Canada.

Hickley, P., and H. Tompkins. editors. 1998. Recreational fisheries: social, economic, and management aspects. Fishing News Books, Oxford, UK.

Hilborn, R., T. A. Branch, B. Ernst, A. Magnusson, C. V. MinteVera, M. D. Scheuerell, and J. L. Valero. 2003. State of the world's fisheries. Annual Review of Environment and Resources 28:359399. http://dx.doi.org/10.1146/annurev.energy.28.050302.105509

Hoeinghaus, D. J., A. A. Agostinho, L. C. Gomes, F. M. Pelicice, E. K. Okada, J. D. Latini, E. A. L. Kashiwaqui, and K. O. Winemiller. 2009. Effects of river impoundment on ecosystem services of large tropical rivers: embodied energy and market value of artisanal fisheries. Conservation Biology 23:1222-1231. http://dx.doi.org/10.1111/j.1523-1739.2009.01248.x

Islam, M. M., M. M. Shamsuzzaman, A. R. Sunny, and N. Islam, N. 2017. Understanding fishery conflicts in the hilsa sanctuaries of Bangladesh. Pages 18-31 in A. M. Song, S. D. Bower, P. Onyango, S. J. Cooke, and R. Chuenpagdee, editors. Inter-sectoral governance of inland fisheries. Too Big To Ignore-WorldFish, St. John's, Newfoundland, Canada.

Jackson, S. 2006. Compartmentalising culture: the articulation and consideration of Indigenous values in water resource management. Australian Geographer 37:19-31. http://dx.doi. org/10.1080/00049180500511947

Jackson, S., M. Storrs, and J. Morrison, J. 2005. Recognition of Aboriginal rights, interests and values in river research and management: perspectives from northern Australia. Ecological Management and Restoration 6:105-110. http://dx.doi.org/10.1111/ j.1442-8903.2005.00226.x

Jenkins, M. 2003. Prospects for biodiversity. Science 302:11751177. http://dx.doi.org/10.1126/science.1088666

Jentoft, S. 2007. In the power of power: the understated aspect of fisheries and coastal management. Human Organization 66:426437. http://dx.doi.org/10.17730/humo.66.4.a836621h2k5x46m2

Kearney, R. E. 2002. Recreational fishing: value is in the eye of the beholder. Pages 17-33 in T. J. Pitcher, and C. E. Hollingworth, editors. Recreational fisheries: ecological, economic and social evaluation. Blackwell Science, Oxford, UK. http://dx.doi. org/10.1002/9780470995402.ch2

Kurian, M. 2004. Institutional analysis of integrated water resources management in river basins - a methodology paper. Working Paper 79. International Water Management Institure, Colombo, Sri Lanka.

Lavrakas, P. J. 2008. Encyclopedia of survey research methods. Sage Publications, Thousand Oaks. http://dx.doi.org/10.4135/9781412963947

Lebel, L., P. Garden, and M. Imamura. 2005. The politics of scale, position, and place in the governance of water resources in the Mekong region. Ecology and Society 10(2): 18. http://dx.doi. org/10.5751/ES-01543-100218
Leifeld, P. 2018. Discourse network analysis: poolicy debates as dynamic networks. Pages 301-326 in J. N. Victor, A. H. Montgomery, and M. Lubell, editors. The Oxford handbook of political networks. Oxford University Press, Oxford, UK.

Lewis-Beck, M. S., A. Bryman, and T. Futing Liao. 2004. The SAGE encyclopedia of social science research methods. Sage Publications, Thousand Oaks, California, USA. http://dx.doi. org/10.4135/9781412950589

Liu, J., V. Hull, M. Batistella, R. DeFries, T. Dietz, F. Fu, et al. 2013. Framing sustainability in a telecoupled world. Ecology and Society 18(2):26. http://dx.doi.org/10.5751/ES-05873-180226

Lorenzen, K., I. G. Cowx, R. E. M. Entsua-Mensah, N. P. Lester, J. D. Koehn, R. G. Randall, et al. 2016. Stock assessment in inland fisheries: a foundation for sustainable use and conservation. Reviews in Fish Biology and Fisheries 26:405-440. http://dx.doi. org/10.1007/s11160-016-9435-0

Lubell, M. 2013. Governing institutional complexity: the ecology of games framework. Policy Studies Journal 41:537-559. http:// dx.doi.org/10.1111/psj.12028

Lukes, S. 1974. Power: a radical view. Macmillan, London, UK.

Lynch, A. J., T. D. Beard Jr., A. Cox, Z. Zarnic, S. C. Phang, C. C. Arantes, et al. 2016a. Drivers and synergies in the management of inland fisheries: Searching for sustainable solutions. Pages 183200 in C. Goddard, N. Leonard, W. W. Taylor, and D. Bartley, editors. Freshwater, fish, and the future: proceedings of the global cross-sectoral conference. American Fisheries Society, Bethesda, Maryland, USA.

Lynch, A. J., S. J. Cooke, T. D. Beard, Jr., Y. -C. Kao, K. Lorenzen, A. M. Song, et al. 2017. Grand challenges in the management and conservation of North American inland fish and fisheries. Fisheries 42:115-124. http://dx.doi.org/10.1080/03632415.2017.1259945

Lynch, A.J., S. J. Cooke, A. M. Deines, S. D. Bower, D. B. Bunnell, I. G. Cowx, et al. 2016b. The social, economic, and environmental importance of inland fish and fisheries. Environmental Reviews 24:115-121. http://dx.doi.org/https://doi.org/10.1139/er-2015-0064

Lynch, A.J., B. J. E. Myers, C. Chu, L. A. Eby, J. A. Falke, R. P. Kovach, et al. 2016c. Climate change effects on North American inland fish populations and assemblages. Fisheries 41:346-361. http://dx.doi.org/https://doi.org/10.1080/03632415.2016.1186016

Malmqvist, B., and S. Rundle. 2002. Threats to the running water ecosystems of the world. Environmental Conservation 29:134-153. http://dx.doi.org/10.1017/S0376892902000097

Martínez-Alier, J. 2001. Ecological conflicts and valuation: mangroves vs. shrimp in the late 1990s. Environment and Planning C 19:713-728. http://dx.doi.org/10.1068/c15s

McGinnis, M. D., and E. Ostrom. 2014. Social-ecological system framework: Initial changes and continuing challenges. Ecology and Society 19(2): 30. http://dx.doi.org/10.5751/ES-06387-190230

McIntyre, P. B., C. A. R. Liermann, and C. Revenga. 2016. Linking freshwater fishery management to global food security and biodiversity conservation. Proceedings of the National Academy of Sciences 113:12880-12885. http://dx.doi.org/10.1073/ pnas. 1521540113 
Mekong River Commission (MRC). 2010. State of the basin report: 2010 summary. MRC, Vientiane, Laos PDR.

Mhlanga, W., and K. Nyikahadzoi. 2017. Competing claims in a multipurpose lake: mapping resource conflicts on Lake Kariba. Pages 71-83 in A. M. Song, S. D. Bower, P. Onyango, S. J. Cooke, and R. Chuenpagdee, editors. Inter-sectoral governance of inland fisheries. Too Big To Ignore-WorldFish, St. John's, Newfoundland, Canada.

Morrison, T. H., W. N. Adger, K. Brown, M. C. Lemos, D. Huitema, D., and T. P. Hughes. 2017. Mitigation and adaptation in polycentric systems: sources of power in the pursuit of collective goals. WIRES Climate Change e479. http://dx.doi. org/10.1002/wcc.479

Navrud, S. 2001. Economic valuation of inland recreational fisheries: empirical studies and their policy use in Norway. Fisheries Management and Ecology 8:369-382.

Nayak, P. K, D. Armitage, M. Andrachuk. 2016. Power and politics of social-ecological regime shifts in the Chilika lagoon, India and Tam Giang lagoon, Vietnam. Regional Environmental Change 16:325-339. http://dx.doi.org/10.1007/s10113-015-0775-4

Nayak, P. K., and F. Berkes. 2014. Linking global drivers with local and regional change: a social-ecological system approach in Chilika Lagoon, Bay of Bengal. Regional Environmental Change 14:2067-2078. http://dx.doi.org/10.1007/s10113-012-0369-3

Neiland, A. E., and C. Béné. 2006. Tropical river fisheries valuation: a global synthesis and critical review. International Water Management Institute, Colombo, Sri Lanka.

Nelson, C. H., K. Lowitt, M. Nagy, and D. Bavington, D. 2013. Future research approaches to encourage small-scale fisheries in the local food movement. Journal of Agriculture, Food Systems, and Community Development 3:177-181. http://dx.doi.org/10.5304/ jafscd.2013.034.020

Nguyen, V. M., A. J. Lynch, N. Young, I. G. Cowx, T. D. Beard Jr., W. W. Taylor, et al. 2016. To manage inland fisheries is to manage at the social-ecological watershed scale. Journal of Environmental Management 181:312-325. http://dx.doi.org/10.1016/ j.jenvman.2016.06.045

Nguyen-Khoa, S., and L. E. D. Smith. 2004. Irrigation and fisheries: irreconcilable conflicts or potential synergies? Irrigation and Drainage 53:415-427. http://dx.doi.org/https://doi.org/10.1002/ $\underline{\text { ird. } 136}$

Noblit, G. W., and R. D. Hare. 1988. Meta-ethnography: synthesising qualitative studies. Sage, Newbury Park, California, USA. http://dx.doi.org/10.4135/9781412985000

Nunan, F., and P. Onyango. 2017. Inter-sectoral governance in inland fisheries: Lake Victoria. Pages 48-57 in A. M. Song, S. D. Bower, P. Onyango, S. J. Cooke, and R. Chuenpagdee, editors. Inter-sectoral governance of inland fisheries. Too Big To IgnoreWorldFish, St. John's, Newfoundland, Canada.

Oosterveer, P. 2006. Globalization and sustainable consumption of shrimp: consumers and governance in the global space of flows. International Journal of Consumer Studies 30:465-476. http://dx. doi.org/10.1111/j.1470-6431.2006.00535.x
Orr, S., J. Pittock, A. Chapagain, and D. Dumaresq. 2012. Dams on the Mekong River: lost fish protein and the implications for land and water resources. Global Environmental Change 22:925932. http://dx.doi.org/10.1016/j.gloenvcha.2012.06.002

O'Sullivan, D., and D. Unwin. 2002. Geographic information analysis. Wiley, Hoboken, New Jersey, USA. http://dx.doi. org/10.1002/9780470549094

Poe, G. L., T. B. Lauber, N. A. Connelly, S. Creamer, R. C. Ready, and R. C. Stedman. 2013. Net benefits of recreational fishing in the Great Lakes Basin: areview of the literature. Cornell University, Ithaca,New York, USA.

Ratner, B. D., P. Cohen, B. Barman, K. Mam, J. Nagoli, and E. H. Allison. 2013. Governance of aquatic agricultural systems: analyzing representation, power, and accountability. Ecology and Society 18(4): 59 http://dx.doi.org/10.5751/ES-06043-180459

Salmi, P., and M. Sipponen. 2017. Cultural strengths and governance challenges of a northern inland fishery. Pages 84-96 in A. M. Song, S. D. Bower, P. Onyango, S. J. Cooke, and R. Chuenpagdee, editors. Inter-sectoral governance of inland fisheries. Too Big To Ignore-WorldFish, St. John's, Newfoundland, Canada.

Sneddon, C. 2007. Nature's materiality and the circuitous paths of accumulation: dispossession of freshwater fisheries in Cambodia. Antipode 39:167-193. http://dx.doi.org/10.1111/ j.1467-8330.2007.00511.x

Sneddon, C., and C. Fox. 2012. Inland capture fisheries and large river systems: a political economy of Mekong fisheries. Journal of Agrarian Change 12:279-299. http://dx.doi.org/10.1111/ j.1471-0366.2011.00350.x

Söderbaum, P. 1999. Values, ideology and politics in ecological economics. Ecological Economics 28:161-170. http://dx.doi. org/10.1016/S0921-8009(98)00139-6

Song, A. M. 2018. How to capture small-scale fisheries' many contributions to society? - introducing the 'value-contribution matrix' and applying it to the case of a swimming crab fishery in South Korea. Pages 125-146 in D. S. Johnson, T. G. Acott, N. Stacey, J. Urquhart, editors. Social wellbeing and the values of small-scale fisheries. Springer, Dordrecht, The Netherlands. http://dx.doi.org/10.1007/978-3-319-60750-4 6

Song, A., and R. Chuenpagdee R. 2013. The damage schedule approach. Pages 279-299 in M. Bavinck, R. Chuenpagdee, S. Jentoft, and J. Kooiman, editors. Governability of fisheries: theory and applications. Springer, Dordrecht, The Netherlands. http:// dx.doi.org/10.1007/978-94-007-6107-0 15

Song, A. M., S. D. Bower, P. Onyango, S. J. Cooke, and R. Chuenpagdee, editors. 2017. Inter-sectoral governance of inland fisheries. TBTI Publication Series, E-01/2017. Too Big To IgnoreWorldFish. St John's, Newfoundland, Canada.

Taylor, W. W., D. M. Bartley, C. I. Goddard, N. J. Leonard, and R. Welcomme, editors. 2016. Freshwater, fish and the future: proceedings of the global cross-sectoral conference, Rome, Italy, 2015. Food and Agriculture Organization of the United Nations, Rome, Italy; Michigan State University, East Lansing, Michagan, USA; American Fisheries Society, Bethesda, Maryland, USA. 
Tezzo, X., Y. Kura, E. Baran, Z. Z. Wah. 2017. Individual tenure and commercial management of Myanmar's inland fish resources. Pages 111-121 in A. M. Song, S. D. Bower, P. Onyango, S. J. Cooke, and R. Chuenpagdee, editors. Inter-sectoral governance of inland fisheries. Too Big To Ignore-WorldFish, St. John's, Newfoundland, Canada.

Vaidyanathan, G. 2011. Remaking the Mekong. Science 478:305307.

Visseren-Hamakers, I. J. 2015. Integrative environmental governance: enhancing governance in the era of synergies. Current Opinion in Environmental Sustainability 14:136-143. http://dx. doi.org/10.1016/j.cosust.2015.05.008

Vörösmarty, C. J., P. B. McIntyre, M. O. Gessner, D. Dudgeon, A. Prusevich, P. Green, et al. 2010. Global threats to human water security and river biodiversity. Nature 467:555-561. http://dx.doi. org/10.1038/nature09440

Weitz, N., C. Strambo, E. Kemp-Benedict, and M. Nilsson, M. 2017. Closing the governance gaps in the water-energy-food nexus: insights from integrative governance. Global Environmental Change 45:165-173. http://dx.doi.org/10.1016/j.gloenvcha.2017.06.006

Welcomme, R. L. 2001. Inland fisheries: ecology and management. Blackwell Science, Oxford, UK. http://dx.doi.org/10.1002/9780470995693

Welcomme, R. L., I. G. Cowx, D. Coates, C. Béné, S. Funge-Smith, A. Halls, et al. 2010. Inland capture fisheries. Philosophical Transactions of the Royal Society B: Biological Sciences 365:28812896. http://dx.doi.org/10.1098/rstb.2010.0168

Winemiller, K. O., P. B. McIntyre, L. Castello, E. FluetChouinard, T. Giarrizzo, S. Nam, et al. 2016. Balancing hydropower and biodiversity in the Amazon, Congo, and Mekong. Science 351:128-129. http://dx.doi.org/10.1126/science. aac7082

World Bank. 2012. Hidden harvest: the global contribution of capture fisheries. The World Bank, Washington, D.C., USA

World Bank. 2014. Myanmar: ending poverty and boosting prosperity in a time of transition, a systematic country diagnostic. The World Bank, Washington, D.C., USA. [online] URL: https:// openknowledge.worldbank.org/bitstream/handle/10986/23121/930500CSD0P150070Box385388B000U0090.pdf?sequence=1\&isAllowed= $\mathrm{y}$ http://dx.doi.org/10.1596/24584

Youn, S. -J., W. W. Taylor, A. J. Lynch, I. G. Cowx, T. D. Beard, D. Bartley, et al. 2014. Inland capture fishery contributions to global food security and threats to their future. Global Food Security 3:142-148. http://dx.doi.org/10.1016/j.gfs.2014.09.005

Ziv, G., E. Baran, S. Nam, I. Rodríguez-Iturbe, and S. A. Levin. 2012. Trading-off fish biodiversity, food security, and hydropower in the Mekong River basin. Proceedings of the National Academy of Sciences 109:5609-5614. http://dx.doi.org/10.1073/pnas.1201423109 
Appendix. Case studies at-a-glance

\begin{tabular}{|c|c|c|c|c|c|}
\hline Contributors & Environment & Sectors involved & Key narrative(s) & $\begin{array}{l}\text { Time period } \\
\text { covered }\end{array}$ & $\begin{array}{l}\text { Featured } \\
\text { discipline(s) }\end{array}$ \\
\hline Islam et al. & $\begin{array}{l}\text { Meghna and } \\
\text { Padma Rivers } \\
\text { (Bangladesh) }\end{array}$ & $\begin{array}{l}\text { Mechanized and non- } \\
\text { mechanized boat fishing groups, } \\
\text { fish traders/ middlemen and } \\
\text { NGOs, various government } \\
\text { bureaus instituting or supporting } \\
\text { a fishing ban }\end{array}$ & $\begin{array}{l}\text { Examines the causes of conflicts and social } \\
\text { tensions among various groups surrounding hilsa } \\
\text { sanctuaries as they relate to increased competition } \\
\text { over fishing space and irregularities in } \\
\text { distribution of } \\
\text { economic incentives }\end{array}$ & Present & $\begin{array}{l}\text { Natural resources } \\
\text { studies }\end{array}$ \\
\hline Baer et al. & $\begin{array}{l}\text { Upper Lake } \\
\text { Constance } \\
\text { (Germany- } \\
\text { Switzerland- } \\
\text { Austria) }\end{array}$ & $\begin{array}{l}\text { Commercial capture fishery; } \\
\text { aquaculture; tourism; drinking } \\
\text { water; nature conservation }\end{array}$ & $\begin{array}{l}\text { Constructs a history of nutrient dynamics and } \\
\text { lake water quality driven by factors external to } \\
\text { fishery, and describes the varied impacts this has } \\
\text { created on lake ecology and on different water- } \\
\text { based sectors including capture fishery }\end{array}$ & $\begin{array}{l}\text { Early } 20^{\text {th }} \text { century to } \\
\text { present }\end{array}$ & $\begin{array}{l}\text { Lake and fish } \\
\text { ecology }\end{array}$ \\
\hline $\begin{array}{l}\text { Nunan and } \\
\text { Onyango }\end{array}$ & $\begin{array}{l}\text { Lake Victoria } \\
\text { (Tanzania- } \\
\text { Kenya-Uganda) }\end{array}$ & $\begin{array}{l}\text { Three main commercial fisheries } \\
\text { - Nile perch, Nile tilapia and } \\
\text { dagaa; agriculture; forestry }\end{array}$ & $\begin{array}{l}\text { Outlines the history of fisheries governance, and } \\
\text { discusses inter-sectoral conflicts and cooperation } \\
\text { by taking into account the multi-level and trans- } \\
\text { boundary setup of the lake }\end{array}$ & $\begin{array}{l}\text { Late } 20^{\text {th }} \text { century to } \\
\text { present }\end{array}$ & $\begin{array}{l}\text { Natural resources } \\
\text { studies }\end{array}$ \\
\hline $\begin{array}{l}\text { Hettiarachchi and } \\
\text { Morrison }\end{array}$ & $\begin{array}{l}\text { Urban wetlands } \\
\text { in Kolkata and } \\
\text { Colombo (India } \\
\text { and Sri Lanka) }\end{array}$ & $\begin{array}{l}\text { Waste water-fed pond } \\
\text { pisciculture; capture fisheries; } \\
\text { agriculture (rain-fed rice } \\
\text { cultivation); real-estate } \\
\text { development; urban use of water }\end{array}$ & $\begin{array}{l}\text { Compares the governance and fisheries/ecological } \\
\text { outcomes in two urban wetlands in South Asia } \\
\text { and analyses the factors that led to different } \\
\text { trajectories }\end{array}$ & $\begin{array}{l}\text { Colonial (late } 19^{\text {th }} \\
\text { and early } 20^{\text {th }} \\
\text { centuries) to post- } \\
\text { colonial to present }\end{array}$ & $\begin{array}{l}\text { Wetland ecology; } \\
\text { environmental } \\
\text { history; } \\
\text { institutional } \\
\text { analysis }\end{array}$ \\
\hline $\begin{array}{l}\text { Mhlanga and } \\
\text { Nyikahadzoi }\end{array}$ & $\begin{array}{l}\text { Lake Kariba } \\
\text { (Zambia- } \\
\text { Zimbabwe) }\end{array}$ & $\begin{array}{l}\text { Inshore gillnet fishery; offshore } \\
\text { kapenta fishery; cage } \\
\text { aquaculture; recreational fishery; } \\
\text { tourism and hospitality; wildlife } \\
\text { management; hydropower } \\
\text { generation }\end{array}$ & $\begin{array}{l}\text { Discusses various intra-sectoral and inter-sectoral } \\
\text { conflicts observed in Lake Kariba, and } \\
\text { governance arrangements for the fisheries at } \\
\text { national and bi-national levels }\end{array}$ & $\begin{array}{l}\text { Late } 20^{\text {th }} \text { century to } \\
\text { present }\end{array}$ & $\begin{array}{l}\text { Natural resources } \\
\text { studies }\end{array}$ \\
\hline $\begin{array}{l}\text { Salmi and } \\
\text { Sipponen }\end{array}$ & $\begin{array}{l}\text { Finnish lakes } \\
\text { (Finland) }\end{array}$ & $\begin{array}{l}\text { Commercial fishery; recreational } \\
\text { fishery; wildlife conservation }\end{array}$ & $\begin{array}{l}\text { Describes how commercial fishery gets } \\
\text { marginalized vis-à-vis recreational fishery and } \\
\text { seal conservation, and discusses the importance } \\
\text { of local food movement and new governance } \\
\text { arrangements for altering the power relations }\end{array}$ & $\begin{array}{l}\text { Late } 20^{\text {th }} \text { century to } \\
\text { present }\end{array}$ & $\begin{array}{l}\text { Natural resources } \\
\text { studies }\end{array}$ \\
\hline
\end{tabular}




\begin{tabular}{|c|c|c|c|c|c|}
\hline Bower et al. & $\begin{array}{l}\text { Cauvery River } \\
\text { (India) }\end{array}$ & $\begin{array}{l}\text { Subsistence fishery, recreational } \\
\text { fishery, hydropower generation, } \\
\text { sand mining }\end{array}$ & $\begin{array}{l}\text { Introduces the fishery, management measures and } \\
\text { governance structures, and describes conflicts } \\
\text { between recreational and subsistence fisheries } \\
\text { and other inter-sectoral issues }\end{array}$ & Present & $\begin{array}{l}\text { Natural resources } \\
\text { studies; fish } \\
\text { ecology }\end{array}$ \\
\hline Tezzo et al. & $\begin{array}{l}\text { Ayeyarwady } \\
\text { Delta (Myanmar) }\end{array}$ & $\begin{array}{l}\text { Open-access fishery; leasable } \\
\text { fishery (privately leased); rice } \\
\text { cultivation }\end{array}$ & $\begin{array}{l}\text { Describes the origin, evolution, limitations, } \\
\text { prospects and estimated values of 'leasable' } \\
\text { fisheries, and suggests research recommendations }\end{array}$ & $\begin{array}{l}\text { Colonial }\left(19^{\text {th }} \text { and }\right. \\
20^{\text {th }} \text { century) to } \\
\text { present }\end{array}$ & $\begin{array}{l}\text { Natural resources } \\
\text { studies; } \\
\text { institutional } \\
\text { analysis }\end{array}$ \\
\hline Singh and Gupta & $\begin{array}{l}\text { The mid-Ganga } \\
\text { basin in the } \\
\text { Ganga River } \\
\text { (India) }\end{array}$ & $\begin{array}{l}\text { Capture fishery; colonial } \\
\text { interests in revenue extraction } \\
\text { and fish conservation }\end{array}$ & $\begin{array}{l}\text { Describes the 'diara' ecology, and explains how } \\
\text { the British colonial government established state } \\
\text { control over waterbodies which led to } \\
\text { privatization and loss of water access for river- } \\
\text { dependent fishing communities }\end{array}$ & $\begin{array}{l}\text { Colonial }\left(18^{\text {th }} \text { and }\right. \\
19^{\text {th }} \text { century) }\end{array}$ & $\begin{array}{l}\text { Environmental } \\
\text { history }\end{array}$ \\
\hline $\begin{array}{l}\text { Akintola and } \\
\text { Fakoya }\end{array}$ & $\begin{array}{l}\text { Badagry Creek } \\
\text { (Nigeria) }\end{array}$ & $\begin{array}{l}\text { Capture fishery; water } \\
\text { transportation; sand mining; eco- } \\
\text { tourism }\end{array}$ & $\begin{array}{l}\text { Provides a succinct yet comprehensive account of } \\
\text { the fishery, social context and governance } \\
\text { arrangements as well as inter-sectoral } \\
\text { relationships with other lagoon-based activities }\end{array}$ & $\begin{array}{l}\text { Pre-colonial to } \\
\text { present }\end{array}$ & $\begin{array}{l}\text { Natural resources } \\
\text { studies; cultural } \\
\text { history }\end{array}$ \\
\hline Gurung and Sah & $\begin{array}{l}\text { Koshi Tappu } \\
\text { flood plains in } \\
\text { Saptakoshi River } \\
\text { (Nepal) }\end{array}$ & $\begin{array}{l}\text { Capture fishery; wildlife } \\
\text { conservation park; tourism; sport } \\
\text { fishing }\end{array}$ & $\begin{array}{l}\text { Describes fishery characteristics and conflicts } \\
\text { between fishing and wildlife conservation, and } \\
\text { proposes community-involved fishing tourism as } \\
\text { a win-win solution }\end{array}$ & Present & $\begin{array}{l}\text { Natural resources } \\
\text { studies }\end{array}$ \\
\hline
\end{tabular}

